\title{
Desalento, descrença, desencanto e desesperança: o perfil poético do emigrado português em terras brasileiras
}

\section{Discouragement, disbelief, disenchantment and hopelessness: the poetic profile of Portuguese emigrants in Brazilian lands}

\author{
Maria Clara Costa Pereira ${ }^{1}$
}

\section{Resumo}

\begin{abstract}
Este artigo busca imergir por entre as expressões poéticas publicadas no jornal carioca A Saudade (18551857 e 1861-1862) sobre sentimentos de desalento, descrença, desencanto e desesperança em relação ao presente e futuro, investigando formas de construção de uma sensibilidade e um perfil literário melancólicos. Assim como estas enunciações estão em relação com um estilo artístico próprio deste contexto histórico, também, é por meio delas que uma experiência particular, do grupo de portugueses emigrados no Rio de Janeiro, de afastamento e saudade é significada e apropriada como forma de identificação e conforto existencial e social. O jornal funciona, nesse sentido, como obra a partir da qual determinadas construções, sentimentais e artísticas, ganham visibilidade. Periódico do Grêmio Literário Português, este órgão é enunciado enquanto representante da associação e vincula projetos sob o signo da literatura e instrução, funcionando como meio de construção de uma ethos sensível do português emigrado em meio aos embates sociais da sociedade brasileira oitocentista.
\end{abstract}

Palavras-chave: Literatura. Imprensa. Identidade. Melancolia.

\begin{abstract}
This article seeks to immerse among the poetic expressions published in the Rio de Janeiro newspaper A Saudade (1855-1857 and 1861-1862) about feeling of discouragement, disbelief, disenchantment and hopelessness in relation to the present and future, investigating ways of construction of a sensitivity and a literary profile, both melancholy. Just as these statements are related to an artistic style typical of this historical context, it is also through them that a particular experience, of the group of Portuguese immigrants in Rio de Janeiro, of remoteness and saudade is significant and appropriate as a way of identification and existential and social comfort. The newspaper functions, in this sense, as a work from which certain, sentimental and artistic, constructions gain visibility. Periodical of the Grêmio Literário Português, this organ is enunciated as a representative of the association and links projects under the sign of literature and instruction, working as a way of construction a sensitive ethos of Portuguese emigrants in the midst of the social clashes of $19^{\text {th }}$ century Brazilian society.
\end{abstract}

Keywords: Literature. Press. Identity. Melancholy.

A Saudade - Publicação Literária e Instrutiva é um periódico do Grêmio Literário Português, associação de portugueses residentes no Rio de
Janeiro da segunda metade do século XIX, que teve duas séries publicadas, sendo a primeira entre os anos de 1855 e 1857 (com três volumes que

\footnotetext{
${ }^{1}$ Doutoranda em Estudos Literários na Universidade Federal de Uberlândia (UFU), Uberlândia, Minas Gerais, Brasil. E-mail: makla10@hotmail.com
} 
correspondem respectivamente a três semestres) e a segunda entre os anos de 1861 e 1862 (chegando a quase um ano e meio de existência). O jornal semanal é marcado por textos em prosa e poesia com temáticas sobre a pátria, a infância, o exílio, a sociedade moderna, a religião cristã, a necessidade da instrução pela literatura, especialmente para os portugueses emigrados, como forma de regeneração (termo recorrentemente utilizado no periódico) de sua imagem perante a sociedade e, inclusive, como instrumento de reforma moral. A Saudade se situa, nesse sentido, dentro de um fazer político e artístico que busca delimitar um espaço para seu grupo identitário.

Fundado a partir de uma distensão do Gabinete de Leitura Português que, como escreve Sébastien Rozeaux, se deu em decorrência de um "conflito de gerações que teria oposto os fundadores do gabinete de leitura a seus membros mais jovens" (ROZEAUX, 2016, p. 495), o Grêmio é composto por jovens amantes da literatura, que se diferenciam e se sentem marginalizados no campo das letras por não possuírem formação acadêmica, de forma que é na associação que encontram e constroem um espaço próprio para seus estudos e, principalmente, publicação de seus trabalhos com o intuito de conquistar um reconhecimento, engrandecendo a imagem do português emigrado tanto para a sociedade brasileira quanto portuguesa. Tal como escreve Victor Andrade de Melo e Fabio de Faria Peres:

A criação de agremiações, assim, pode ser entendida como uma estratégia de afirmação e conformação da comunidade lusitana. Atendia tanto à necessidade de auto-organização, para melhor encarar os problemas enfrentados no Brasil e para celebrar a relação com a pátria distante, quanto ao desejo de demonstrar à sociedade brasileira o valor da colônia portuguesa, sendo também uma forma de intervenção política (MELO; PERES, 2013, p. 247).
Os jovens portugueses redatores e leitores d'A Saudade, sua maioria trabalhadores do comércio, exercem esta ação política, inclusive, por meio da expressão, ao mesmo tempo construção, de uma sensibilidade, uma forma histórica e coletiva de sentir que funciona unindo e identificando seu grupo. O termo saudade aparece, assim, como bandeira de um modo de ser e fazer; é com ele que são narrados e cantados os afetos individuais e coletivos que marcam as histórias de peregrinação e vivência em terra estrangeira, significando os anseios existenciais deste grupo e projetando transformações sociais sob a máxima da religiosidade cristã e o estudo da literatura e história portuguesa. Neste processo, o periódico se alinha a determinados estilos literários em diálogo com seu contexto histórico, com destaque para romantismo em que a expressão íntima de sentimentos de sofrimento funciona como uma reação ao presente moderno.

O desalento.

Oh! Minha esperança

Morrerei comtigo.

Minha doce ilusão, onde ora foste?

Que me não trazes mais f'lizes lembranças

D'um contado porvir?!...

Não respondes ingrata, e meus clamores

Espargidos no espaço, pouco a pouco

Acabam de zumbir.

Agora és fenecida, o desengano

Te matou sem piedade, e eu partilhei

Do teu cruel destino!

Ai! Morrerei também, quero comtigo

Acabar os meus dias, sem ventura, Que vida... desatino!

Aquelles lindos sonhos, d'outras horas, Que me vinham de ti, quando eu dormia, Já hoje os não profiro.

Vida sem esperanças, desfallece!

Prazeres sem futuros, oh! Deixai-me! Adeos, ai! que eu espiro!...

(CASTRO, 1856) $)^{2}$.

\footnotetext{
${ }^{2}$ Assim como neste poema, nos demais textos publicados no jornal $A$ Saudade e transcritos neste artigo, é mantida a grafia original.
} 
O poema de Castro é significativo para iniciar estas reflexões em torno da composição poética de uma identidade literária melancólica, uma vez que se volta para uma interlocutora sugestiva: a ilusão. O "eu" canta para um "tu" que é, ao mesmo tempo, propriedade sua, parte de si, porém, perdida na relação do tempo passadopresente. Esta ilusão é personagem metafórica e construída com adjetivações e ações humanizadas; ela é ingrata e passível de ações. Ações estas que a matam, sem piedade. Assim o lamento sobre si é voltado para fora de si por meio do termo ilusão metaforizado como outrem. A morte da ilusão é a própria morte do eu lírico que compartilha do cruel destino. Trata-se, portanto, de um cantar íntimo, de si para si, na significação da vida própria. A ideia vinculada ao poema é de que o fim da ilusão é o fim do ser. O poema é um canto de lamento da vida sem ilusão, do fenecimento que é ocasionado por esta experiência. A própria visualidade e sonoridade do poema compõe este sentido, uma vez que o afastamento nos versos 3 e 6 fazem de sua rítmica mais curta, funcionando como um encerramento de ideia, e construindo uma sensação de lamento.

A recorrência de poemas destinados ao canto de dor ocasionado pela morte da mulher amada é uma constante na poesia romântica, em especial, a de língua portuguesa no século XIX. Porém, aqui, a morte lamentada é de parte do eu lírico. Morte cujo autor é o desengano. Desalento, desengano, desatino... Estes substantivos utilizados no poema se valem do prefixo "des" para dar sentido oposto aos termos (alento, engano, atino) que não compõe mais a experiência sensível do eu lírico, mas que caracterizavam as ilusões d'outras horas. Esta transformação é o mote do cantar de pesar do eu lírico, situado em um estilo literário romântico cuja modalidade própria, como entendem Michael Löwy e Robert Sayre, se funda numa crítica ao mundo moderno, no sentido em que:

De fato, na óptica romântica essa crítica está vinculada à experiência de uma perda; no real moderno uma coisa preciosa foi perdida, tanto no nível do indivíduo quanto no da humanidade. A visão romântica caracteriza-se pela convicção dolorosa e melancólica de que o presente carece de certos valores humanos essenciais, que foram alienados. Senso agudo da alienação, então, frequentemente vivido como exílio (LÖWY; SAYRE, 2015, p. 43).

O que foi perdido para o "eu" romântico, melancólico em relação ao presente, extrapola a ordem individual; não se restringe a expressão de um "estado de alma", mas comunica uma sensibilidade e uma perspectiva histórica e coletiva em relação ao mundo.

Esta experiência é fundamentalmente uma experiência literária. Não caberia uma investigação da vida do autor para relacioná-la ao que é cantado, mas, antes, pensar esta enunciação em diálogo com seu contexto histórico e cultural. Este ethos literário, marca do romantismo, é potencializado como forma de expressão de um "eu" enquanto representante de um "nós", que, no caso de um poema publicado n'A Saudade (jornal de um grupo que se identifica pela condição do desterro), potencializa a vivência na realidade concreta de uma peregrinação coletiva, do afastamento forçado de sua terra natal e habitação num país repleto de sentimentos antilusitanos. Sobre as relações entre brasileiros e portugueses, identidades em movimento e formação no século XIX, escreve Gladys Sabina Ribeiro (2002, p. 63): "Incentivase o medo contra o estrangeiro, o 'português', que de tão conhecido foi transformado em 'inimigo', e sobre ele passou-se a divulgar estereótipos... E é claro que isto gerava perseguições, controle e vigilância”. Nesta sociedade, a importância da constituição de uma associação, um espaço que possibilite o estar entre iguais, compartilhar ideias e sentimentos é forma de resistência às aversões aos portugueses. Segundo Eduardo Marandola Júnior e Priscila Marchiori Dal Gallo:

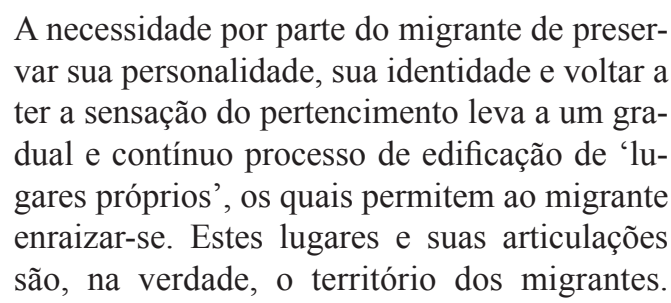

A necessidade por parte do migrante de preservar sua personalidade, sua identidade e voltar a ter a sensação do pertencimento leva a um gradual e contínuo processo de edificação de 'lugares próprios', os quais permitem ao migrante enraizar-se. Estes lugares e suas articulações são, na verdade, o território dos migrantes. 
Esses lugares se configuram como base e fundamento das redes sociais estabelecidas por eles (MARANDOLA JÚNIOR; DAL GALLO, 2010, p. 412).

O jornal é meio de construção de um território, um lugar próprio, do grupo, assim como suas publicações comunicam e definem sentimentos que dizem tanto do sentir quanto do fazer artístico que identifica estes sujeitos. Saudade, melancolia e desalento são signos do perfil do português emigrado e residente no Brasil na segunda metade dos oitocentos. Os poemas de desalento, descrença, desencanto e desesperança que aparecem recorrentemente n'A Saudade não são publicações desconexas aos embates históricos e sociais, mas funcionam paradoxalmente expondo dores para combatê-las, cantando impossibilidades como forma de resistência e crítica ao mundo e à sociedade.

\section{Descrença.}

Pende, pende, minha lyra, E não mais cantos m'inspira Que falem apenas d'amor; Obedece ao sentimento Que me mata a fogo lento, Obedece á minha dor.

Já cantaste com ternura, Um passado de ventura, Um passado sem senão; Hoje só tristes endêxas Em tuas cordas me deixas Vibrar sem doce illusão.

Como risonho era o dia Em que contente podia $\mathrm{Na}$ lyra cantar amor! Eram felizes momentos Pois que doces sentimentos Eu cantava com primor.

Recordei em ti gostoso O momento saudoso Em que soube ser amado, E em ti symbolisei O que mais então amei Sempre alegre - descuidado.

Eu bem sei que tristemente Te verás hoje pendente Esquecida - desprezada;
Porém sinto que mais tarde

Ha-de vir a saudade

Dizer que sejas chamada.

Mas em quanto q'esse dia

Não venha doce alegria

Ao coração despertar;

Pende, pende, minha lyra,

Mas não mais cantos me inspira

Que fallem sempre d'amar.

Rio, Maio 4 de 1856

(PINTO, 1856).

Assim como no poema de Barbosa de Castro, sob a pena de Antonio Xavier Rodrigues Pinto (um dos principais redatores d'A Saudade) também são cantadas as diferenças entre um passado feliz e um presente triste. Apesar das diferentes autorias, o jornal $A$ Saudade encerra um projeto uno de forma que sua abordagem é fundamentada na compreensão do periódico enquanto obra literária coesa. Assim, as construções individuais se tocam e se relacionam, participando de um fazer coletivo no qual o "eu" da escrita aponta diretamente para um "nós".

Em "Descrença", em diálogo com o que acontece em "O desalento", o prefixo no termo que dá título ao poema compõe a ideia que perpassa os versos de perda de algo, de ausência daquilo (crença e amor) que no presente habita apenas o passado, fazendo do eu lírico a expressão da melancolia. Esta condição é comunicativa, considerando que os leitores (assim como redatores) do jornal são emigrados, cujo apartamento da terra natal é marca de sua identidade, de seu ser, ou seja, a poesia que tem por máxima a temática da diferenciação qualitativa e afetiva destes dois tempos toca de forma potencializada e significativa as emoções deste público leitor em especial.

A interlocução do poema anterior se metaforizava pelo uso do termo ilusão, neste é a lira, ou seja, seu fazer: o cantar. O lamento do eu lírico se fundamente, justamente, naquilo que ele faz; ele canta a incapacidade de cantar, ou melhor, a incapacidade de cantar cantos de amor. De sua lira só saem sofrimentos e descrenças para com o seu presente, uma postura tanto melancólica quanto 
romântica. Merquior problematiza este perfil poético do melancólico enquanto homem sem projeto, descrente, mas cuja descrença é já expressão do triunfo que lhe cabe: "Este, afinal é o único projeto permitido ao melancólico, ao homem sem projeto: a superação pela arte. O puro e incontaminado triunfo do canto - e nada mais." (MERQUIOR, 2016). Nesse sentido, a incapacidade funciona como forma de resistência, expressão do incômodo e projeto de transformação que se anuncia, no poema de Rodrigues Pinto, com o uso da palavra saudade.

A saudade é palavra-chave para o estudo do jornal como meio de construção de um espaço do português emigrado no Brasil; ela é título do conjunto, de forma que nomeia e identifica ao passo que indica passado (na pátria), presente (na terra estrangeira) e futuro (no retorno) comum. Ela é o sentir que faz cada membro pertencer ao coletivo. Ainda que em relação semântica a melancolia, seu uso de distingue pelo movimento que lhe é intrínseco, ou seja, pelo desejo de busca e transformação do presente, tendo o passado como referencial. Nas palavras de Hilário Franco Júnior (2017, p. 153): "Assim, enquanto melancolia é tristeza tão paralisante que esquece o passado, esvazia o presente, anula o futuro, saudade além de presente voltado para o passado e passado vivenciado no presente, é também presente dirigido para o futuro graças ao ato de fé que é a esperança.". Não por acaso o termo nomeia o periódico. Com este "batismo", imbui na imprensa as esperanças e forças para realização do projeto coletivo, assim como no poema é o meio de doce alegria ao coração despertar.

Esta temática pode ser, ainda, potencializada por meio da reflexão do poema, de título próximo ao de Barbosa de Castro, "Desalento" de João Dantas de Sousa:

\section{Desalento.}

Eu não quero tanger mais a lyra

Em que amores outr'ora cantei....

Eu não quero poisar mais a vista

N'esses cantos que dela arranquei!...

Eu não quero em memoria esse tempo
Que d'amores vivi illudido....

Eu não quero que viva na mente

A cruel que o amor há trahido!...

Eu não quero d'amor em minh'alma

Essas chamas ardendo sentir....

Eu não quero já mais sobre a terra

De ninguém os carinhos fruir!...

Eu não quero que nestes meus labios

Um sorriso me venha pairar....

Eu não quero oh! não quero do mundo

Gozos futeis já mais disfructar!...

Eu não quero manter mais a esp'rança

Com que louco té qui hei vivido....

Eu só quero fugir aos enganos

Deste mundo fallaz e mentido!...

Eu só quero viver em silencio,

Longe, ás vistas do mundo fugir!...

Eu só quero... mas ai! nada posso!

E' forçoso meu fado cumprir!!!

Setembro

(SOUSA, 1856).

Neste poema, as temáticas que já apareceram com outras assinaturas, também, são abordadas: a lira representando o cantar do eu lírico que no presente está suprimido em contraposição ao passado que ganha sentido de tempo repleto de ilusões e amores. A diferenciação entre os tempos, em que o passado é idílico e o presente indesejado, acompanha o sentido construído nos versos de uma incapacidade, ou ainda, renúncia de cantar amores. A paralisia melancólica é uma imagem potente e presente nas primeiras estrofes em que imobilidade e desalento caracterizam a condição do eu lírico.

A passagem de um tempo (passado) para o outro (presente) e, consequentemente, de uma percepção sensível (amores) para a outra (desalento) ganha um marco neste poema. Ainda que não seja o mote sobre o qual o eu lírico canta, sua transformação se revela em decorrência de uma experiência de traição: Eu não quero que viva na mente a cruel que o amor há traído!... O que foi ou o que ocasionou esta experiência de traição não é revelado, porém, é a partir dela que todo o universo é ressignificado. $\mathrm{O}$ eu lírico se torna transtornado e 
o mundo figurado como falaz e mentido, de gozos fúteis e enganos. Daí o impulso de fuga.

A anáfora "eu não quero", que inicia e repete nos versos 1 e 3 até a quinta estrofe, canta o desencanto do eu lírico em relação à vida, porém, sofre uma modificação significativa da penúltima para a última estrofe, passando a ser "eu só quero". Esta transformação que ocorre justamente no final do poema, é arremate da ideia de uma paralisação que funciona como seu oposto. $\mathrm{O}$ desejo por não cantar, lembrar e amar parece situar o eu lírico numa condição estática que se rompe com modificação das últimas estrofes, em que a falta de projeto (que, como Merquior escreve, é a marca do melancólico) ganha movimento e impulso de fuga. Este é o projeto do eu lírico: Eu só quero fugir aos enganos Deste mundo falaz e mentido!... Longe, ás vistas do mundo fugir!... Como escreve Bachelard:

Então, na superfície do ser, nessa região onde o ser quer manifestar-se e quer esconder-se, os movimentos de fechamento e abertura são tão numerosos, tão frequentemente invertidos, tão carregados também de hesitação, que poderíamos concluir por esta Fórmula: o homem é o ser entreaberto (BACHELARD, 1993, p. 225).

Esta característica do ser na poesia enfoca a dialética do mundo exterior e interior. Tal como em "Desalento", estas instâncias se misturam. A dor interna está vinculada às imagens do mundo falaz. Daí a necessidade de fugir e se abrigar contra este mundo. A impossibilidade de fazê-lo é arremate do poema com a entrega do eu lírico ao seu destino, seu fado. Tal resolução está em diálogo com a figura do poeta romântico enquanto aquele que carrega a difícil missão de cantar suas dores, ainda que não queira, e de expressar a angústia em relação ao mundo e à passagem do tempo. A pontuação compõe este perfil, ao mesmo tempo, marcado pela força e pelo lamento; as reticências e exclamações no final dos versos 2 e 4 compõe a rítmica e, consequentemente, o sentido de dor que ressoa e indignação com que é cantado o tomento do eu lírico, respectivamente. Com destaque para os versos finais (Eu só quero... mas ai! nada posso! E' forçoso meu fado cumprir!!!) em que a missão do canto de dor se sobrepõe ao desejo de fuga, fazendo do poeta romântico e melancólico um paladino da expressão artística e sensível na contramão do mundo moderno.

Desalento.

Como custa o soffrer! como é sangrento O punhal d'uma dôr quando se imbebe No coração transido!

A. Lima.

Vida de crenças, d'illusões chimericas. Ai! quão depressa para mim fugiste; Fanal incerto em trevas tão dourada luz: Foi breve o tempo que sorriu benefico; Punge-me agora bem cruel saudade D'essa tão pura quão feliz idade Que em seus enlevos só amor traduz.

Porque te involves n'esse veu fatidico Qual sombra errante que no mundo vaga? Quem dera ao menos que em saudosa plaga Cheio d'esperanças eu te fosse vêr!...

Oh! se eu pudesse n'um só beijo candido, Singelo e puro, d'uma irmã querida, Beber as crenças de sorrir da vida, Gosar venturas, e depois morrer!...

Oh! se eu pudesse d'esse anjo pudico Que sempre em sonhos a sorrir eu vejo, Ir sobre os labios com ardente beijo Sellar a jura que lhe fiz d'amor! Então a vida que sonhei magnífica Inda de certo para mim voltára, E' nessa estancia tão amena e cara Vivera a vida da mimosa flôr.

Mas esse tempo que passou tão rapido Deixando o vacuo que inda sinto n'alma, Levou comsigo minha doce calma, Lançou de rojo minha crença ao chão; Veio a descrença qual funesto oraculo Ralou-me o peito d'infinitas dores, Fugiu-me a vida, já não tenho amores, Porque em minha'alma já não ha paixão.

Se d'essa vida que gosei pacifica Qual lindo arroio que a correr doideja, Acaso o peito recordar deseja Doces instantes que a sorrir passei; Depressa vejo que meu rosto pallido Dá signal certo de que soffro, e gemo: 
E é porisso que lembrar-me temo

D'essas delicias que na infancia achei.

Soffro em silencio, porque no tumulo Terminarei o meu sofrer constante; Embalde busco um coração amante Que em seus arroubos comprehenda o meu; Se ás vezes, triste, pensativo e tremulo, Eu sonho um anjo, ou ideal formoso, Vou, solitário, suspirar saudoso, Fim a meus males implorar ao ceu.

(LIMA, 1861a).

O título deste poema, e o fato de ser publicado na segunda série d'A Saudade, o situa em diálogo com as temáticas e autores até então problematizados, porém o poema não estabelece relações apenas com a obra periódica na qual está veiculado. A epígrafe funciona como intertexto que revela referenciais externos, afinal, trata-se de um trecho do poema "Antes a morte" de A. Lima (1853) publicado no periódico literário português "O Trovador" (Coimbra, 1844-1848), de forma que a citação estabelece uma ponte entre o fazer artístico do português emigrado com sua pátria e as criações literárias que lhe são próprias.

O perfil melancólico do eu lírico também é construído no poema de A. José de Carvalho Lima (que assina a maioria de suas publicações da segunda série d'A Saudade como C. L.). O presente que revela o passado enquanto tempo de ilusões significa a relação sensível de dor do interior com o exterior. O que resta do tempo passado? A primeira estrofe responde: A saudade, cruel. A palavra saudade é mais uma vez ponto chave na composição poética, tanto por seu caráter identitário e cultural como por sua semântica que transita entre bom e o ruim, ou, para utilizar adjetivações de Almeida Garrett recorrentemente mencionadas no jornal, doce e amargo. O referido poeta português é uma referência fundacional para a literatura portuguesa do século XIX, de forma que seu poema "Camões" é considerado marco inicial do romantismo em Portugal. Nele, os primeiros versos significam a saudade em diálogo com sentidos e ideias utilizados por diversos escritores de língua portuguesa ao longo da segunda metade do século XIX e no século XX: "Saudade! gôsto amargo de infelizes,/ Delicioso pungir de acerbo espinho,/ Que me estás repassando o íntimo peito/ Com dor que os seios d'alma dilacera, / - Mas dor que tem prazeres Saudade!"' (GARRETT, 1858, p. 1).

Se no poema de Antonio Xavier Rodrigues Pinto a saudade é salvadora, no sentido em que expressa o projeto que libertará o eu lírico de sua condição de cantar apenas sofrimento e não mais amores, no poema de Carvalho Lima, a saudade é cruel, pois é o que revela a discrepância entre os tempos, fazendo do passado referencial para uma dor que se potencializa no presente em decorrência do tempo breve que sorriu benéfico. Estas construções não são contraditórias, mas, antes, operam dentro da ambivalência intrínseca dos usos da palavra saudade, que fazem dela signo da identidade portuguesa sob o discurso de sua intraduzibilidade para outros idiomas justamente por ser utilizada e adjetivada de maneira complexa. N'A Saudade, porém, é possível compreender como o termo funciona para delimitar um território dos sujeitos que se sentem representar pela associação e pelo jornal, um sentir e um fazer artístico, marcado por um presente (triste e exilado, tal como pode ser percebido no verso qual sombra errante que no mundo vaga?) contraposto por um passado (feliz individualmente e glorioso nacionalmente). O periódico tomado pelo conjunto de suas publicações, com especial enfoque nos poemas de viés melancólico, são formas de situar sujeitos e ações de acordo com uma sensibilidade, portanto, portuguesa e romântica. Como escreve Eduardo Lourenço sobre a relação da saudade na literatura portuguesa com o romantismo:

Será preciso esperar até o Romantismo por uma leitura tão perspicaz e tão digna da saudade, do seu mistério ou do seu enigma. O Romantismo fará entrar na História, principalmente na nossa, essa imagem sublime. O Romantismo português não é outra coisa senão a leitura da história de Portugal como avatar da saudade e, inversamente, da saudade como avatar da nossa História (LOURENÇO, 1999, p. 30). 
O jornal $A$ Saudade é aqui considerado obra participante deste processo de leitura, de perspectiva em relação ao mundo, ao "eu", ao "nós" e ao "outro".

O desalento e a saudade do eu lírico são, ainda, vinculados ao amor e à morte, elementos que carregam novas camadas de significação para o projeto romântico. Assim como nos demais poemas, o amor perpassa o lamento do eu; é por ter existido no passado, porém, não mais no presente, que a dor, descrença e desalento dizem do íntimo do eu lírico: Porque em minha 'alma já não há paixão. A morte também contribui com a constituição do perfil melancólico do poeta; ela aparece como resolução do sofrimento: no tumulo terminarei o meu sofrer constante. $\mathrm{O}$, por assim dizer, flerte com a morte é característica de parte das publicações do romantismo, sendo a única resolução, ou ainda, certeza que se revela como transcendência do presente de dor.

Este poema, diferente dos apresentados até então, faz parte da segunda série do jornal. A. José de Carvalho Lima é um autor cujas contribuições nesta série são instigantes para estas discussões. $\mathrm{Na}$ sequência, as reflexões são em torno de publicações de sua autoria, sendo "Desencanto" próximo de "Desalento" para pensar as construções de sentidos e perfis poéticos em torno do sofrimento em decorrência de um presente desprovido de ilusões, assim entendidas e findadas por uma traição que marca o rompimento com o passado de amor.

Desencanto.

Porque desfolhou tão breve?...

A. Campos.

Sobre o cálix d'uma rosa Minha vida fui depôr;

Meus prazeres, meus suspiros,

Eu dei tudo á lindo flor.

Tudo, tudo; e mais lhe dera

Se mais tivesse que dar:

Pois se a rosa era tão bela

No seu lindo desabrochar!...

Se era! - tinha no cálix

Doce perfume do ceu;
Ao viço de suas folhas Meu coração se rendeu.

Era a flor dos meus amores

Onde a minha crença puz;

Era, nas trevas da vida,

A minha estrella de luz.

Era o pensamento unico

Do meu continuo sonhar;

Era a letra mais querida

Que eu sabia decifrar.

Eu amava-a tanto, tanto, Com tão delirante amor,

Que ás vezes tinha ciúme

Da belleza d'outras flor.

Tinha ciumes da aurora

Que vinha a rosa orvalhar,

Tinha ciumes da brisa

Porque a vinha bafejar...

Entretanto, a linda rosa

Curvou-se, um dia, ao tufão:

Deu-lhe as folhas, deu-lhe tudo,

Deu-lhe até... meu coração.

Não quizera amor tão santo

Como aquelle que the dei:

Destruiu as minhas crenças,

Se vivo agora... não sei!

(LIMA, 1861b).

Até então os poemas apresentados têm como título os termos desalento e descrença. Este último insere uma nova palavra para operar dentro do discurso poético e melancólico do jornal: desencanto. O prefixo "des", mais uma vez, funciona para anunciar a ausência e, até mesmo, inversão do termo encanto (em proximidade semântica com ilusão, amores e sonhos), ou seja, se institui com base numa dicotomia (entre encanto e desencanto, passado e presente, doce e amargo, prazeres e dores), mote da angústia do eu lírico.

$\mathrm{O}$ uso do termo desencantamento é significativo neste contexto, uma vez que ele aparece em obras literárias, filosóficas e sociológicas ao longo do século XIX e XX como emblema de uma transformação material e, principalmente, mental e afetiva da sociedade. Em 1919, Max Weber defende: 
O destino de nossos tempos é caracterizado pela racionalização e intelectualização e, acima de tudo, pelo 'desencantamento do mundo'. Precisamente os valores últimos e mais sublimes retiraram-se da vida pública, seja para o reino transcendental da vida mística, seja para a fraternidade das relações humanas diretas e pessoais (WEBER apud LÖWY; SAYRE, 2015, p. 52).

Em proximidade com os processos de secularização e mecanização da sociedade, o desencantamento do mundo é chave reflexiva para se pensar as transformações nos comportamentos e relações humanas, baseada na ideia de perda de algo importante e belo (religiosa ou moralmente) que existiu num passado, mas que se encontra degradado no presente. Daí que determinadas correntes literárias e filosóficas, em diálogo com esta perspectiva, apresentem produções calcadas numa resposta melancólica e saudosa, como meio de crítica e resistência à realidade. Nesse sentido, as publicações poéticas d'A Saudade se relacionam com seus textos filosóficos em prosa, cujas temáticas se fundamentam a favor da reforma moral e social, assim como da renovação baseada na religiosidade cristã; são expressões operando dentro de uma mesma perspectiva e um mesmo projeto. A imagem final, no poema, de um eu lírico apático e imóvel, que não sabe se vive em decorrência de uma desilusão, um desencantamento, é repleta de movimento para fora de si e é um documento que evidencia como tais ideias não estão restritas ao meio acadêmico e intelectual, mas se apresentam, inclusive, na imprensa periódica luso-brasileira, representante de um grupo associativo que se anuncia enquanto amadores das letras, ainda que não profissionais da área. A condição de emigrados e exilados destes sujeitos casam com as angústias frente a novas sensibilidades, especialmente, por elas aprofundarem a sensação de distância com um passado idílico.

A novidade de "Desencantamento" para estas reflexões em relação aos demais poemas, também, se dá no sentido em que o título anuncia o desencanto em relação à vida e ao mundo, porém, seus versos cantam majoritariamente o encanto do passado. Neste processo a linguagem metafórica é extremamente rica. A relação do eu lírico com a flor comunica uma experiência de devoção, amor e, por fim, morte, ou ainda, traição. O final pode ser interpretado como perecimento da rosa perante o tufão, ou este enquanto rival amoroso e vitorioso: Entretanto, a linda rosa curvou-se, um dia, ao tufão: deu-lhe as folhas, deu-lhe tudo, deu-lhe até... meu coração. A traição, de qualquer forma, está implicada, enquanto elemento poético, ao sentido de morte, pois este é vivido como uma traição que o mundo comete em relação ao eu lírico, funcionando como o marco, já mencionado, de ruptura entre passado de amores e prazeres, e presente de sofrimentos e lamentos.

Finalizando o conjunto de poemas d'A Saudade selecionados para pensar a construção do "eu" poético desvinculado da ânsia pela vida e pelo presente, segue mais uma publicação de A. José de Carvalho Lima no número de encerramento do primeiro ano da segunda série do jornal. Um número significativo para dizer das desesperanças deste "nós" que luta para a manutenção do periódico, sempre ameaçada pela falta de condições materiais...

\section{Desesperança}

Horas felizes que passei na infancia, De vós já não esqueci,

Já morreram meus sonhos de ventura,

Já passou essa quadra, em que tão pura Doce vida frui!

Ai! passou, como passa o meteoro Pelo ceu a luzir;

Como a aragem da briza pela flôres

Segredando seus místicos amores Que morrem a sorrir.

Se recordo essas horas tão felizes D'alegrias sem fim,

Sinto o pranto rolar-me pela face, Pois não ha uma esperança que se enlace De ventura p'ra mim!

Esperança! o que és, aonde existes? Oh não te sinto, não! 
Esperar! e porque? se n'este mundo

Só encontro a descrença - o mal profundo

Que mata o coração?!

Esperar! - Pela morte, sim, espero

Sem tristeza e sem dôr;

Nada tenho na vida que seduza,

E minh'alma descrente, e só - recusa

A vida sem amor!

Mas não mendiga, não, o sentimento

Que a fizera viver,

Oh! não, porque se a vida é assaz breve,

Tão puro sentimento, ainda assim - deve

Espontaneo nascer.

Sem um sorriso que me alente as crenças

Em breve morrerei;

Sem pesar deixarei tão triste vida,

Fujo ao mundo cruel que me intimida,

No ceu repousarei.

Eu bem sei que não hade uma só lagrima

Ninguem por mim chorar;

Ainda assim morrerei bem satisfeito.

Findarão estas dôres de meu peito,

Deixarei de penar!

(LIMA, 1862).

Este poema é um dentre tantos outros cujas temáticas de dores presentes e passados saudosos que não retornam recheiam os versos destinados aos leitores d'A Saudade. A infância, em que tão pura doce vida frui, tem poder imagético potencializado se referenciada numa situação de exílio; ela não apenas habita outro tempo, como também outro espaço, forçosamente distante. A memória do tempo gera dor, uma vez que o eu lírico é, neste poema, essencialmente melancólico, sem projeto, ou seja, sem esperança: Pois não há uma esperança que se enlace de ventura para mim! E ainda: Esperança! O que és, aonde existes? Oh não te sinto, não! Daí o título do poema: Desesperança. Este é último termo apresentado que intitula os poemas deste artigo e utiliza o prefixo "des" na composição do perfil melancólico do eu lírico.

$\mathrm{O}$ exterior encontra-se em relação com o interior neste canto de desesperança, uma vez que o mundo se revela desencantado e o eu lírico, consequentemente, descrente: Esperar! E porque? Se neste mundo só encontro a descrença - o mal profundo. Qual é, então, a resolução para tal condição? Novamente, a morte. Esta aparece como a espera na vida do eu lírico, o seu desejado repouso, a fuga possível: Em breve morrerei; sem pesar deixarei tão triste vida, fujo ao mundo cruel que me intimida, no céu repousarei. Tal morte é solitária e o mundo indiferente a ela (eu bem sei que não há de uma só lágrima ninguém por mim chorar), porém, ainda assim ela é o projeto deste homem sem projeto, por meio dela são findadas as dores, nela encerra toda a negação ao mundo.

Neste poema é possível perceber a própria composição visual em diálogo com o conteúdo melancólico dos versos. O afastamento no início dos versos 2 e 5, além de destacar o poema em relação aos demais (instigando o leitor para sua leitura), participa da construção de um sentido de introversão e lamento, uma vez que os espaços se encontram nos versos com a métrica reduzida, de forma que a leitura com eles parece ritmar um suspirar.

Este poema reúne sistematicamente as temáticas que foram tomando corpo ao longo da leitura e problematização das imagens e sentidos dos poemas anteriores. Sua composição é madura e profunda. A melancolia, a dicotomia entre tempos e sentimentos e o projeto que é fundamentalmente uma negação ao mundo se concretizam nos versos.

O conjunto de poemas apresentados revela tanto questões sobre o fazer artístico e romântico, como político e histórico. Afinal, estas não são práticas dissociadas. O português emigrado no Brasil é sujeito participante das reações à sociedade moderna, assim como à sociedade carioca que o marginaliza, de forma que a criação de associações e veículos de publicações de obras literárias funcionam estabelecendo um território que lhe é próprio e no qual significa suas experiências de vida individual e coletiva. Como escreve Eduardo Cruz sobre o Grêmio Literário e suas publicações:

Apesar da vida curta, o Grêmio Literário Português no Rio de Janeiro conseguiu congregar nomes importantes do período, que conviveram 
e dividiram espaço com escritores menores e mesmo com jovens imigrantes que apenas queriam mais estudo e alguns momentos de lazer. Mesmo com toda a dificuldade, esses jovens literatos publicaram três vezes periódicos para dar publicidade a suas próprias produções literárias, que ficaram para a posteridade e nos permitiram hoje conhecer um pouco do que faziam e como viviam (CRUZ, 2019, p. 40).

\section{Referências}

BACHELARD, G. A poética do espaço. São Paulo: Martins Fontes, 1993.

CASTRO, J. J. B. O desalento. A Saudade: Periódico Literário, Rio de Janeiro, v. 2, n. 10, p. 78, 13 abr. 1856. (Série I).

CRUZ, E. Obras tão dignas de memória: os periódicos do Grêmio Literário Português do Rio de Janeiro. Revista Moara, Belém, n. 52, p. 28-42, jan./jul. 2019. Doi: 10.18542/moara.v0i52.7809. Disponível em: https://bit.ly/3eG1QSU. Acesso em: set. 2020.

FRANCO JÚNIOR, H. "Saudade", memória do paraíso. Romania, París, v. 135, p. 139-180, 2017.

GARRETT, A. Camões. 5. ed. Lisboa: Casa da viúva Bertrand e Filhos, 1858.

LIMA, A. Antes a morte. In: O TROVADOR: Coleção de poesias contemporâneas. 2. ed. Leiria: Typographia Leiriense, 1853. p. 315. Disponível em: https://bityli.com/bT5IY. Acesso em: 20 set. 2020.

LIMA, A. J. C. Desalento. A Saudade: Periódico Literário, Rio de Janeiro, n. 2, p. 14-15, 30 abr. 1861a. (Série II).

LIMA, A. J. C. Desencanto. A Saudade: Periódico Literário, Rio de Janeiro, n. 13, p. 115, 6 out. 1861b. (Série II).

LIMA, A. J. C. Desesperança, A Saudade: Periódico literário, Rio de Janeiro, n. 25, p. 234-235, 23 mar. 1862. (Série II).

LOURENÇO, E. Mitologia da saudade: seguido de Portugal como destino. São Paulo: Companhia das Letras, 1999.
LÖWY, M.; SAYRE, R. Revolta e melancolia: o romantismo na contramão da modernidade. Tradução: Nair Fonseca. 1. ed. São Paulo: Boitempo, 2015.

MARANDOLA JÚNIOR, E.; DAL GALLO, P. M. Ser migrante: implicações territoriais e existenciais da migração. Revista Brasileira de Estudos de População, São Paulo, v. 27, n. 2, p. 407-424, jul./dez. 2010. Doi: 10.1590/S010230982010000200010. Disponível em: https:// bityli.com/dNm3P. Acesso em: set. 2020.

MELO, V. A.; PERES, F. F. Associativismo e política no Rio de Janeiro do Segundo Império: o Clube Ginástico Português e o Congresso Ginástico Português. Topoi, Rio de Janeiro, v. 15, n. 28, p. 242-265, jan./jun. 2013. Doi: 10.1590/2237101X015028010. Disponível em: https://bityli. com/076q1. Acesso em: set. 2020.

MERQUIOR, J. G. Razão do poema: ensaios de crítica e de estética. São Paulo: É Realizações Editora, 2016.

PINTO, A. X. R. Descrença. A Saudade: Periódico literário. Rio de Janeiro, v. 2, n. 13, p. 104, 4 maio 1856. (Série I).

RIBEIRO, G. S. A liberdade em construção: identidade nacional e conflitos antilusitanos no primeiro reinado. Rio de Janeiro: Relume Dumará, 2002.

ROZEAUX, S. Presença da "colônia portuguesa" na paisagem cultural e mediática do Rio de Janeiro: o Grêmio Literário Português e o Retiro Literário Português (1855-1885). Topoi, Rio de Janeiro, v. 17, n. 33, p. 490-513, jul./dez. 2016. Doi: 10.1590/2237-101x01703308. Disponível em: https://bit.ly/34rJRuQ. Acesso em: set. 2020.

SOUSA, J. D. Desalento. A Saudade: Periódico Literário, Rio de Janeiro, v. 3, n. 7, p. 56, 12 out. 1856. (Série I).
Recebido em: 29 nov. 2020 Aceito em: 24 fev. 2021 
Pereira, M. C. C. 